This item was submitted to Loughborough's Research Repository by the author.

Items in Figshare are protected by copyright, with all rights reserved, unless otherwise indicated.

\title{
Development of a QFD based collaborative design approach to reduce work- related musculoskeletal disorders (MSDs)
}

PLEASE CITE THE PUBLISHED VERSION

\section{PUBLISHER}

(C) Common Ground

\section{VERSION}

VoR (Version of Record)

\section{LICENCE}

CC BY-NC-ND 4.0

\section{REPOSITORY RECORD}

Punchihewa, Himan K.G., and Diane E. Gyi. 2019. "Development of a QFD Based Collaborative Design Approach to Reduce Work-related Musculoskeletal Disorders (msds)". figshare. https://hdl.handle.net/2134/6014. 
This item was submitted to Loughborough's Institutional Repository (https://dspace.lboro.ac.uk/) by the author and is made available under the following Creative Commons Licence conditions.

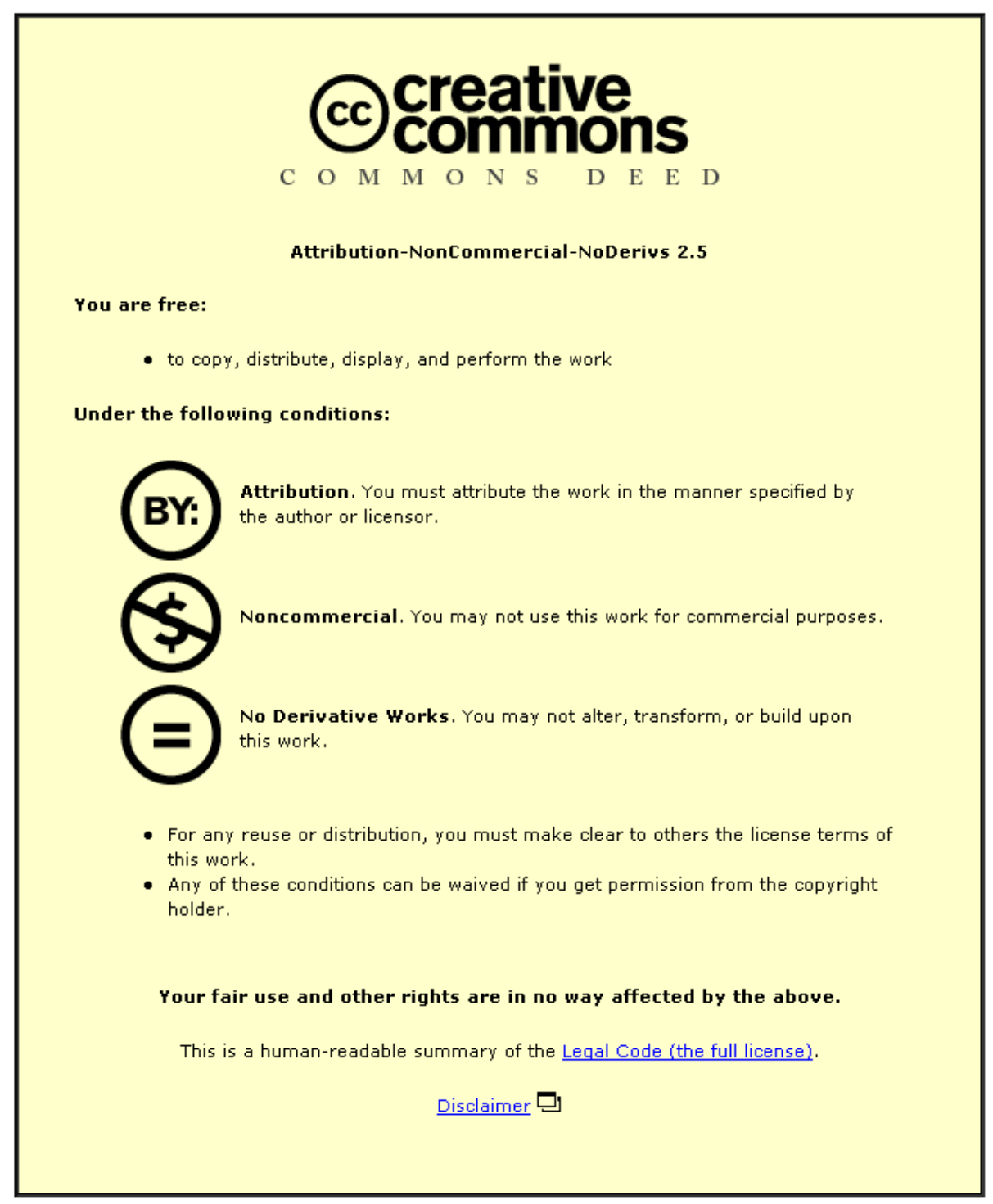

For the full text of this licence, please go to: http://creativecommons.org/licenses/by-nc-nd/2.5/ 


\section{DESIGN}

Principles \& Practices:

An International Journal

Volume 3, Number 6

Development of a QFD Based Collaborative Design Approach to Reduce Work-Related Musculoskeletal Disorders (MSDs)

Himan Kanishka Gardiye Punchihewa and Diane Elizabeth

Gyi 


\section{DESIGN PRINCIPLES AND PRACTICES: AN INTERNATIONAL JOURNAL http://www.Design-Journal.com}

First published in 2009 in Champaign, Illinois, USA by Common Ground Publishing LLC www.CommonGroundPublishing.com.

(C) 2009 (individual papers), the author(s)

(C) 2009 (selection and editorial matter) Common Ground

Authors are responsible for the accuracy of citations, quotations, diagrams, tables and maps.

All rights reserved. Apart from fair use for the purposes of study, research, criticism or review as permitted under the Copyright Act (Australia), no part of this work may be reproduced without written permission from the publisher. For permissions and other inquiries, please contact <cg-support@commongroundpublishing.com>.

ISSN: 1833-1874

Publisher Site: http://www.Design-Journal.com

DESIGN PRINCIPLES AND PRACTICES: AN INTERNATIONAL JOURNAL is peerreviewed, supported by rigorous processes of criterion-referenced article ranking and qualitative commentary, ensuring that only intellectual work of the greatest substance and highest significance is published.

Typeset in Common Ground Markup Language using CGCreator multichannel typesetting system

http://www.commongroundpublishing.com/software/ 


\title{
Development of a QFD Based Collaborative Design Approach to Reduce Work-Related Musculoskeletal Disorders (MSDs)
}

\author{
Himan Kanishka Gardiye Punchihewa, Loughborough University, \\ Leicestershire, UK \\ Diane Elizabeth Gyi, Loughborough University, Leicestershire, UK
}

\begin{abstract}
Participatory ergonomics can help reduce the risk factors for musculoskeletal disorders (MSDs). Its potential can be enhanced by increasing user participation and by helping to provide pragmatic solutions to reduce workplace risks. Research is being conducted to examine the potential of a Quality Function Deployment (QFD) based design approach in reducing work-related MSDs by helping to establish design solutions for equipment and processes. In this pursuit, research has been conducted to investigate potential worker involvement in the participatory process by evaluating their ability to identify risks and user requirements for design to help reduce work-related MSDs. Semistructured interviews were conducted with a sample of workers $(n=22)$ in three different case study areas. Their line managers $(n=6)$ were also interviewed. Observations and Rapid Entire Body Assessment (REBA) analysis of the work tasks were carried out to supplement and triangulate the worker interview data. The study showed that the workers were able to identify risks and requirements related to tasks. All the workers expressed concern about manual handling. Issues related to awkward postures were also identified by the majority of workers in all three case study areas. The risks and requirements for task improvement extracted from worker interviews were prioritised and details were added from the researcher observations. Findings will inform the development of a QFD matrix-based collaborative design approach to establish design solutions and potentially reduce work-related MSDs.
\end{abstract}

Keywords: Musculoskeletal Disorders, Participatory Ergonomics, Design Methods, QFD

\section{Introduction}

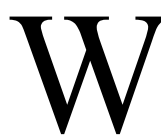

ORK-RELATED MUSCULOSKELETAL DISORDERS (MSDs) constitute $38 \%$ of all illnesses and injuries caused by work according to the Health and Safety Executive (HSE) (2008) estimates. They affect the health and wellbeing of workers and incur costs to industry (Rivilis et al., 2006; Buckle, 2005). A plethora of intervention programmes, standards and guidelines have been developed to reduce the prevalence of MSDs among the working population (Ruotsalainen et al., 2006; Rivilis et al., 2006). Yet, work-related MSDs are still commonplace (HSE, 2008) and research is necessary to improve methods to reduce them (Ruotsalainen et al., 2006).

Participatory approaches have provided effective results in improving working conditions (Kogi, 2006). However, practitioners in general are not involved in all participatory steps (Vink et al., 2008) creating a mismatch between user requirements and what is present in designs. Methodologies and tools for user participation are important elements in participatory

Design Principles and Practices: An International Journal

Volume 3, Number 6, 2009, http://www.Design-Journal.com, ISSN 1833-1874 
approaches (Broberg, 2007) and in supporting practitioners in collaboratively identifying user requirements and suggesting solutions.

Quality Function Deployment (QFD) is a design method that helps integrate user requirements and design (Akao, 1990). A review by Chan and Wu (2002) identifies its application in many industry sectors, and its capability as a design method to fit into different contexts. Previously, there has been limited application of QFD in ergonomics (Marsot, 2005; KuijtEvers et al., 2009). This may be due to its complexity (Iranmanesh et al., 2005; GoncalvesCoelho et al., 2005). These authors consider that the use of selected features of QFD along with other tools that support design can effectively support design. Furthermore, studies of hand tools by Marsot (2005) and Kuijt-Evers et al. (2009) indicate the value of QFD in obtaining and prioritising user requirements and even suggesting solutions to reduce work-related MSDs.

With this notion, a design approach was developed based on QFD and the theory of inventive problem solving (TRIZ) (developed by G.S. Altshuller between 1946 and 1985) (Rantanen and Domb, 2002). This approach, with elements to encompass identifying MSD risks; obtaining user requirements; prioritising these requirements; identifying design solutions to address these requirements; presentation of user requirements/design solutions; checking the feasibility of any solutions; integration of the above elements, and recording knowledge for improvements, is proposed for further research.

A basis for the QFD approach to collaborative design is understanding user ability to specify risks and user requirements to help reduce work-related MSDs. In this pursuit, research was conducted to investigate potential worker (user) involvement in a participatory process by evaluating their ability to identify risks and user requirements for design to help reduce work-related MSDs. This paper presents the findings of this study that will later inform the development of the QFD approach to participatory design.

\section{Data Collection}

The research was conducted in three case study areas to include a variety of work tasks (i.e. cleaning using scrubber drier machines; joinery using workbenches, and plumbing involving varied work tasks). Although the work tasks were purposively selected for the studies, they can be categorised according to three of the four combinations of work tasks and work environments as discussed in literature (Denis et al., 2008). The cleaners' study was a variable environment and cyclic task; the joiners' study was a stationary environment and a variable task, and the plumbers' study was a variable environment and a variable task. All workers (cleaners $(n=10)$, joiners $(n=6)$ and plumbers $(n=6))$ involved in the studied work tasks and their line managers (cleaners' $(n=3)$, joiners' $(n=2)$ and plumbers' $(n=1))$ participated in the research.

Initially, workers were observed for approximately 30 minutes in order to fully understand the particular work tasks. Then, semi-structured interviews were conducted to investigate their perceptions of the workplace risk factors for MSDs and their requirements for design to reduce such risks. The audio-recorded interviews elicited personal information; job information; awareness of MSDs based on the stage of change questionnaire (Whysall et al., 2007); perceived user requirements for the different work tasks by encouraging them to reflect on their work; musculoskeletal troubles (period prevalence- 12 month, point prevalence- 7 day and severity- the effect on normal activities in the last 12 months) based on the Nordic 
musculoskeletal questionnaire (NMQ) (Kuorinka et al., 1987), and involvement in the task design decisions using a 9-point Likert scale $(1=$ no impact at all to $9=$ very high impact scale). Interviews were conducted on site during work time. Probing questions were asked as necessary throughout the interviews to clarify points of interest and to obtain further information.

Workers were directly observed performing the work tasks, and note-taking was guided by work element recording checklists (Konz, 1990). Typical work tasks were captured with a digital camera and task elements were captured on video for approximately 10 minutes. Finally, whole body discomfort (WBD) scales $(0=$ no discomfort to $6=$ extreme discomfort $)$ based on Corlett (1990) were distributed to workers just before and after one hour of work: all worker groups in general worked for one hour slots on a task.

Interviews (semi-structured) were also conducted with line managers to obtain job information; awareness of MSDs based on the manager stage of change questionnaire (Whysall et al., 2007), and the involvement in the task design decisions using a 9-point Likert scale (1= no impact at all to $9=$ very high impact scale).

\section{Analysis}

Firstly, work tasks were analysed using Hierarchical Task Analysis (Annett, 2005) to identify the first level of task elements. Personal and job information were used to obtain characteristics of the worker sample. Then, narratives to the stage of change questionnaire were used to indicate their readiness to change behaviour to reduce the risk of MSDs arising from work and knowledge of work-related MSDs. User-identified risks and requirements were extracted from the interviews and prioritised using the constant comparative method (Glaser, 1965; Erlandson et al., 1993). Prevalence data (period, point and severity) were summarised and compared to the user identified risks and requirements. Mean ratings for the task design decisions were calculated to obtain a measure for the worker involvement in the task design decisions for each of the case study areas.

Note taking, photographs and video recordings were used to add detail and to obtain a clearer picture of the user identified risks and requirements. Video recordings were played back in Windows ${ }^{\circledR}$ Movie Maker and most common and extreme postures were identified by closely observing the work tasks. These postures were used to evaluate risks for MSDs (Spielholz et al., 2001; Bao et al., 2007) using Rapid Entire Body Assessment (REBA) scores (Hignett and McAtamney, 2000). The REBA risks were tabulated with respect to task elements and stature (percentile) of the workers. To document worker discomfort, the mean whole body discomfort rating was calculated for each body area at the beginning of and after one hour of the task.

Characteristics of the manager sample were obtained by analysing job information. Analysis of stage of change data for managers was similar to that of workers'. Then, manager involvement in task design decisions was determined for the three case study areas and details of related procedures were obtained. Manager interviews were also used to triangulate the information provided by the workers. 


\section{Results}

Initial observations were used to understand the elements of the tasks in the three case study areas. Task elements were identified for the mains-operated scrubber drier machines (i.e. filling water and additives, lowering the brush, scrubbing open areas, scrubbing corners and edges, and emptying containers) and for the battery-operated scrubber drier machines (i.e. filling water and additives, scrubbing open areas, scrubbing corners and edges and emptying containers) in the cleaners' study. In the joiners' study, five distinct task elements were observed (i.e. placing material on the workbench, measurement and marking, material removal, finishing and removing the finished job from the workbench). In the plumbers' study, only two broad task elements (i.e. cutting pipes and preparing fittings and connecting the pipes and fittings) were observed.

Characteristics of the worker populations in the three case study areas are shown in Table 1. Only the population of cleaners included both males and females.

Table 1: Characteristics of the Worker Participants $(n=22)$

\begin{tabular}{lccccc}
\hline $\begin{array}{l}\text { Case } \\
\text { study area }\end{array}$ & $\begin{array}{c}\text { Gender } \\
\text { (M/F) }\end{array}$ & $\begin{array}{c}\text { Participant } \\
\text { number }\end{array}$ & $\begin{array}{c}\text { Age (years): } \\
\text { mean (SD) }\end{array}$ & $\begin{array}{c}\text { Height (cm): } \\
\text { mean (SD) }\end{array}$ & $\begin{array}{c}\text { Experience in the job } \\
\text { (years): mean (SD) }\end{array}$ \\
\hline Cleaners' & M & 5 & $46(15)$ & $174(6)$ & $1.6(1.2)$ \\
& F & 5 & $42(13)$ & $159(7)$ & $4.2(4.1)$ \\
Joiners' & M & 6 & $47(14)$ & $176(8)$ & $30.2(13.4)$ \\
Plumbers' & M & 6 & $47(15)$ & $170(8)$ & $30.7(15.1)$ \\
\hline
\end{tabular}

Narratives for the worker stage of change revealed that the majority were in the "contemplation' stage. $80 \%, 83 \%$ and $50 \%$ of workers in the three case study areas (cleaners, joiners and plumbers respectively) suggesting that they had already made changes to their work in the past and intended to make changes if MSD risks were identified. The risks and requirements from the worker interviews were extracted and prioritised. The first six user-identified risks and requirements are listed for the three case study areas in Table 2. For example, all cleaners $(100 \%)$ using the mains-operated machine identified 'the need to lift and carry the dirty water tanks to empty' as a risk. 
Table 2: Prioritised User Identified Risks and Requirements (within brackets, \% of workers expressing concerns)

\begin{tabular}{|c|c|c|c|}
\hline \multicolumn{2}{|c|}{ Cleaners } & \multirow[b]{2}{*}{$\begin{array}{c}\text { Joiners } \\
\text { (workbench) }\end{array}$} & \multirow{2}{*}{$\begin{array}{c}\text { Plumbers (varied } \\
\text { work tasks) }\end{array}$} \\
\hline $\begin{array}{l}\text { Mains-operated } \\
\text { machine }\end{array}$ & $\begin{array}{c}\text { Battery-operated } \\
\text { machine }\end{array}$ & & \\
\hline $\begin{array}{l}\text { Need to lift and carry } \\
\text { the dirty water tanks } \\
\text { to empty [100] }\end{array}$ & $\begin{array}{l}\text { Manoeuvring is } \\
\text { difficult because they } \\
\text { are heavy [60] }\end{array}$ & $\begin{array}{l}\text { Need equipment to } \\
\text { lift and/or move } \\
\text { heavy objects } \\
\text { (materials and } \\
\text { equipment) [100] }\end{array}$ & $\begin{array}{l}\text { Having to lift and } \\
\text { carry objects (tools } \\
\text { and equipment, and } \\
\text { pipes and fittings } \\
\text { etc.) [100] }\end{array}$ \\
\hline $\begin{array}{l}\text { Dirty water tanks are } \\
\text { heavy when filled up } \\
\text { [60] }\end{array}$ & $\begin{array}{l}\text { Speed control is not } \\
\text { sufficient in the } \\
\text { battery operated } \\
\text { machine [30] }\end{array}$ & $\begin{array}{l}\text { Required to plan } \\
\text { work sequences and } \\
\text { material flow to ease } \\
\text { work [83] }\end{array}$ & $\begin{array}{l}\text { Need to eliminate } \\
\text { having to apply } \\
\text { forces while in } \\
\text { awkward postures } \\
\text { [83] }\end{array}$ \\
\hline $\begin{array}{l}\text { Wire interfering with } \\
\text { the work [60] }\end{array}$ & $\begin{array}{l}\text { Suction lines get } \\
\text { clogged [30] }\end{array}$ & $\begin{array}{l}\text { Reduce the } \\
\text { requirement of } \\
\text { having to apply } \\
\text { continuous forces on } \\
\text { work and equipment } \\
\text { sometimes while } \\
\text { being in awkward } \\
\text { postures [67] }\end{array}$ & $\begin{array}{l}\text { Need methods to } \\
\text { prevent having to } \\
\text { keep kneeling for } \\
\text { long durations [83] }\end{array}$ \\
\hline No speed control [40] & $\begin{array}{l}\text { Water gushes out } \\
\text { when emptying the } \\
\text { dirty water tanks [20] }\end{array}$ & $\begin{array}{l}\text { Need adjustable } \\
\text { workbenches for } \\
\text { loading, unloading } \\
\text { and to fit different } \\
\text { work and people [50] }\end{array}$ & $\begin{array}{l}\text { Need to involve in } \\
\text { architectural and } \\
\text { building design to } \\
\text { facilitate plumbing } \\
\text { and other services } \\
\text { [67] }\end{array}$ \\
\hline $\begin{array}{l}\text { Suction lines get } \\
\text { clogged [30] }\end{array}$ & $\begin{array}{l}\text { Handle is not height } \\
\text { adjustable [20] }\end{array}$ & $\begin{array}{l}\text { Reduce impulse } \\
\text { loads and vibration } \\
\text { [50] }\end{array}$ & $\begin{array}{l}\text { Need to design } \\
\text { fittings to ease } \\
\text { installation and } \\
\text { maintenance [50] }\end{array}$ \\
\hline $\begin{array}{l}\text { Having to hold the } \\
\text { operating lever and } \\
\text { the handle } \\
\text { continuously [20] }\end{array}$ & $\begin{array}{l}\text { Battery operated } \\
\text { machines do not } \\
\text { clean as well as the } \\
\text { mains operated ones } \\
{[10]}\end{array}$ & $\begin{array}{l}\text { Need devices to } \\
\text { keep tools for easy } \\
\text { access while working } \\
\text { on the workbench } \\
\text { [50] }\end{array}$ & $\begin{array}{l}\text { Need to reduce high } \\
\text { gripping forces when } \\
\text { using tools [50] }\end{array}$ \\
\hline
\end{tabular}

Figure 1 depicts the prevalence data for the three case study areas. Altogether, $80 \%$ of the cleaners and $100 \%$ of the joiners and plumbers reported at least one musculoskeletal trouble. Cleaners reported (Figure 1.a) a higher period prevalence (40\%) of musculoskeletal troubles in the shoulders, wrists and lower back than in the other regions. Point prevalence of musculoskeletal troubles in the shoulders and lower back was also high (30\%). Joiners (Figure 1.b) reported a higher period prevalence in hands $(67 \%)$ and lower back $(50 \%)$. Severity of musculoskeletal troubles in the lower back $(33 \%)$ was also high. The period prevalence of musculoskeletal troubles in plumbers (Figure 1.c) was very high for the neck (100\%), knees 
(83\%), lower back (83\%) and wrists $(67 \%)$. A very high point prevalence was also reported in the knees $(83 \%)$.

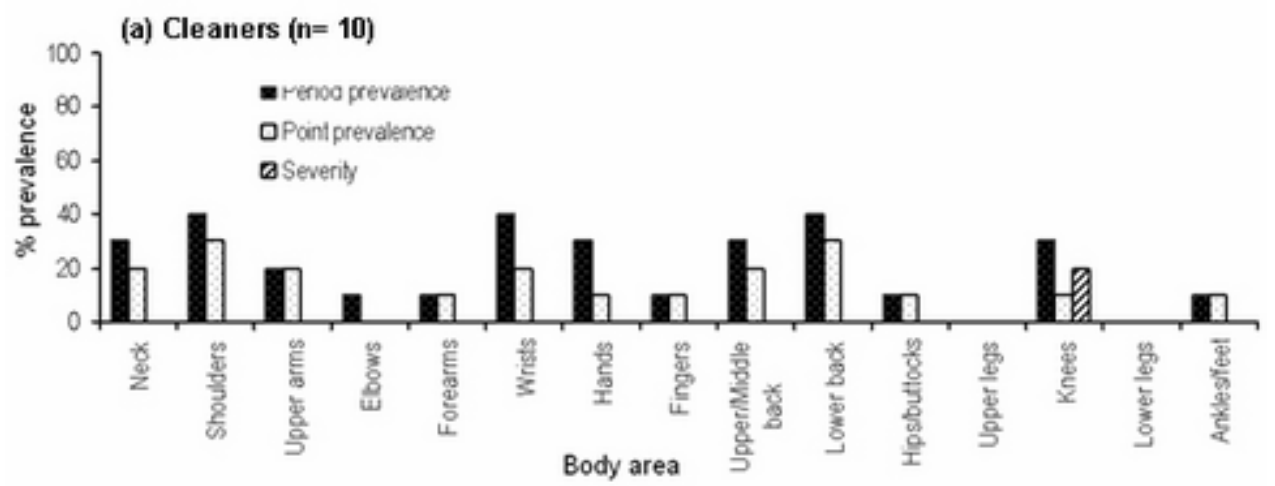

(b) Joiners ( $n=6)$

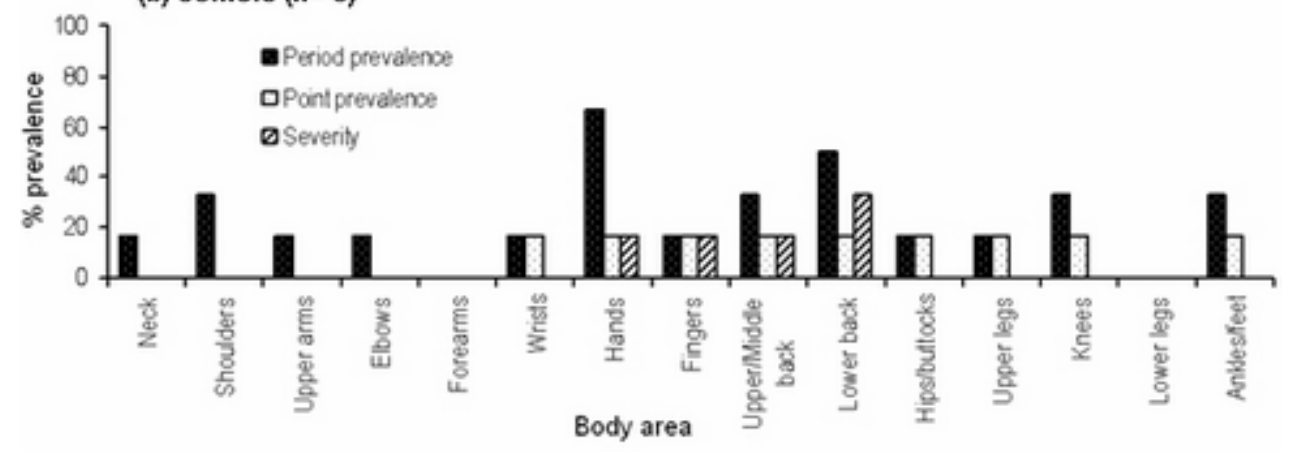

(c) Plumbers $(n=6)$

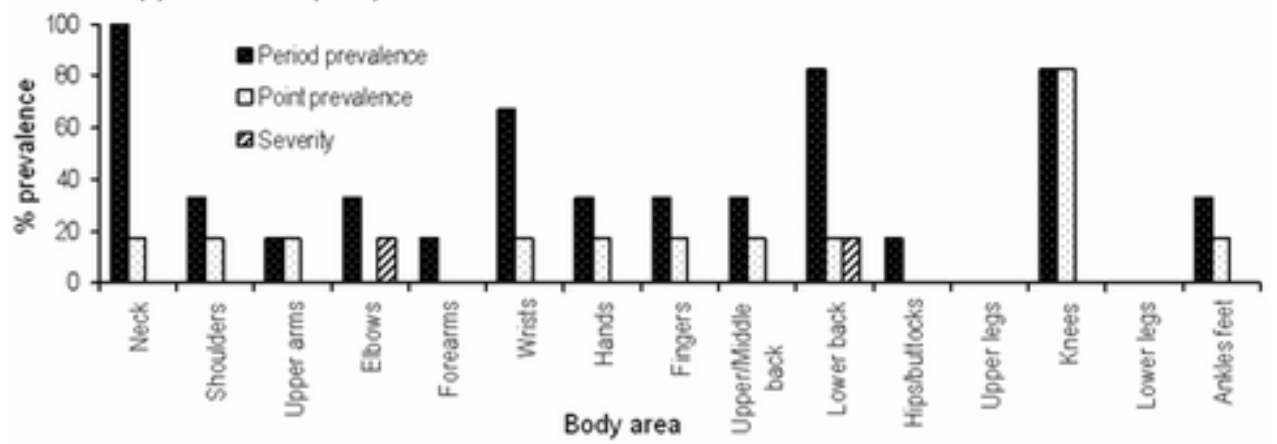

Figure 1: NMQ Data for (a) Cleaners, (b) Joiners and (c) Plumbers

Workers were also asked to judge whether they thought their musculoskeletal troubles were related to work-related factors. Seven out of the eight cleaners that reported musculoskeletal 
troubles judged that they were linked to work-related factors. All joiners and plumbers viewed that their musculoskeletal troubles were linked to work-related factors. For example, three of the four cleaners that reported shoulder troubles associated it to working with the machine (i.e. bending over the machine, heavy equipment and using the machine in general) and the other attributed it to age (i.e. age/arthritis); the joiners that expressed hand troubles (67\%) viewed impact loads, lifting of weights, gripping, holding things while cold, and holding equipment as risk factors; and all the plumbers related neck troubles to awkward postures, bending and twisting.

Cleaners generally rated their involvement in the task design decisions lower (mean $=2$ (SD 1.4)) compared to the joiners and plumbers (mean ratings 4 (SD 2.0) and 5 (SD 1.0) respectively). No correlations were found between the years of experience of the workers and their involvement in the task design decisions.

Tables 3-5 illustrate the REBA risk levels calculated for elements identified from the task analysis in the three case study areas for three cleaners, three joiners and four plumbers.

Table 3: REBA Risk Levels for the Cleaners' Study (with REBA Action Levels)

\begin{tabular}{|c|c|c|c|}
\hline \multirow[b]{2}{*}{ Task element } & \multicolumn{2}{|c|}{ Mains-operated machine } & \multirow{2}{*}{$\begin{array}{l}\text { Battery-operated } \\
\text { machine } \\
\text { Risk level for a } 18^{\text {th }} \\
\text { percentile male }\end{array}$} \\
\hline & $\begin{array}{l}\text { Risk level for a } 7^{\text {th }} \\
\text { percentile female }\end{array}$ & $\begin{array}{l}\text { Risk level for a } 90^{\text {th }} \\
\text { percentile male }\end{array}$ & \\
\hline $\begin{array}{l}\text { Filling water and } \\
\text { additives }\end{array}$ & $\begin{array}{l}\text { Low (May be } \\
\text { necessary) }\end{array}$ & Medium (Necessary) & $\begin{array}{l}\text { Negligible (None } \\
\text { necessary) }\end{array}$ \\
\hline Lowering the brush & $\begin{array}{l}\text { Very high (Necessary } \\
\text { NOW) }\end{array}$ & $\begin{array}{l}\text { Very high (Necessary } \\
\text { NOW) }\end{array}$ & Not applicable \\
\hline $\begin{array}{l}\text { Scrubbing open } \\
\text { areas }\end{array}$ & Medium (Necessary) & Medium (Necessary) & $\begin{array}{l}\text { Negligible (None } \\
\text { necessary) }\end{array}$ \\
\hline $\begin{array}{l}\text { Scrubbing corners } \\
\text { and edges }\end{array}$ & Medium (Necessary) & $\begin{array}{l}\text { High (Necessary } \\
\text { soon) }\end{array}$ & Medium (Necessary) \\
\hline Emptying containers & $\begin{array}{l}\text { High (Necessary } \\
\text { soon) }\end{array}$ & $\begin{array}{l}\text { High (Necessary } \\
\text { soon) }\end{array}$ & $\begin{array}{l}\text { High (Necessary } \\
\text { soon) }\end{array}$ \\
\hline
\end{tabular}


Table 4: REBA Risk Levels for the Joiners' Study (with REBA Action Levels)

\begin{tabular}{|c|c|c|c|}
\hline Task element & $\begin{array}{l}\text { Risk level for a } 24^{\text {th }} \\
\text { percentile male }\end{array}$ & $\begin{array}{c}\text { Risk level for a } 28^{\text {th }} \\
\text { percentile male }\end{array}$ & $\begin{array}{c}\text { Risk level for a } 98^{\text {th }} \\
\text { percentile male }\end{array}$ \\
\hline $\begin{array}{l}\text { Placing material on } \\
\text { the workbench }\end{array}$ & Medium (Necessary) & & \\
\hline $\begin{array}{l}\text { Measurement and } \\
\text { marking }\end{array}$ & Medium (Necessary) & & \\
\hline Material removal & $\begin{array}{l}\text { Medium - High } \\
\text { (Necessary - } \\
\text { Necessary soon) }\end{array}$ & & \\
\hline Finishing & & Medium (Necessary) & $\begin{array}{l}\text { High (Necessary } \\
\text { soon) }\end{array}$ \\
\hline $\begin{array}{l}\text { Removing the } \\
\text { finished job from the } \\
\text { workbench }\end{array}$ & $\begin{array}{l}\text { High (Necessary } \\
\text { soon) }\end{array}$ & & \\
\hline
\end{tabular}

Table 5: REBA Risk Levels for the Plumbers' Study (with REBA Action Levels)

\begin{tabular}{lllll}
\hline Task element & $\begin{array}{c}\text { Risk level for a } \\
\mathbf{1}^{\text {st }} \text { percentile } \\
\text { male }\end{array}$ & $\begin{array}{c}\text { Risk level for a } \\
\mathbf{5 6}^{\text {th }} \text { percentile } \\
\text { male }\end{array}$ & $\begin{array}{c}\text { Risk level for a } \\
\mathbf{2 4}^{\text {th }} \text { percentile } \\
\text { male }\end{array}$ & $\begin{array}{c}\text { Risk level for a } \\
\mathbf{7 2}^{\text {nd }} \text { percentile } \\
\text { male }\end{array}$ \\
\hline $\begin{array}{l}\text { Cutting pipes } \\
\text { and preparing } \\
\text { fittings }\end{array}$ & $\begin{array}{l}\text { Medium } \\
\text { (Necessary) }\end{array}$ & $\begin{array}{l}\text { Very High } \\
\text { (Necessary }\end{array}$ & & \\
$\begin{array}{l}\text { Connecting the } \\
\text { pipes and } \\
\text { fittings }\end{array}$ & $\begin{array}{l}\text { Vow) } \\
\text { (Necessary }\end{array}$ & $\begin{array}{l}\text { Very High } \\
\text { (Necessary }\end{array}$ & $\begin{array}{l}\text { High (Necessary } \\
\text { soon) }\end{array}$ & $\begin{array}{l}\text { Very High } \\
\text { (Necessary }\end{array}$ \\
\hline
\end{tabular}

According to the REBA assessment criteria, for the cleaners, action is necessary immediately for both the $90^{\text {th }}$ percentile male and $7^{\text {th }}$ percentile female in 'lowering the brush' in the mains-operated machine to reduce the risk of MSDs. For the joiners, the REBA assessment criteria indicated that action is necessary especially in 'material removal' and 'removing the finished job' from the workbench in order to reduce the risk of MSDs. REBA also suggests that action is necessary for plumbers particularly with respect to 'connecting the pipes and fittings'.

Mean whole body discomfort (WBD) ratings for all body areas (baseline and after 1 hour) are shown in Figure 2 for the three case study areas. After 1 hour of work, discomfort was particularly a problem in the hands and ankles/feet for cleaners; wrists and hands, and lower back for joiners; and in the neck, lower back and knees for plumbers. 
(a) Cleaners $(n=6)$

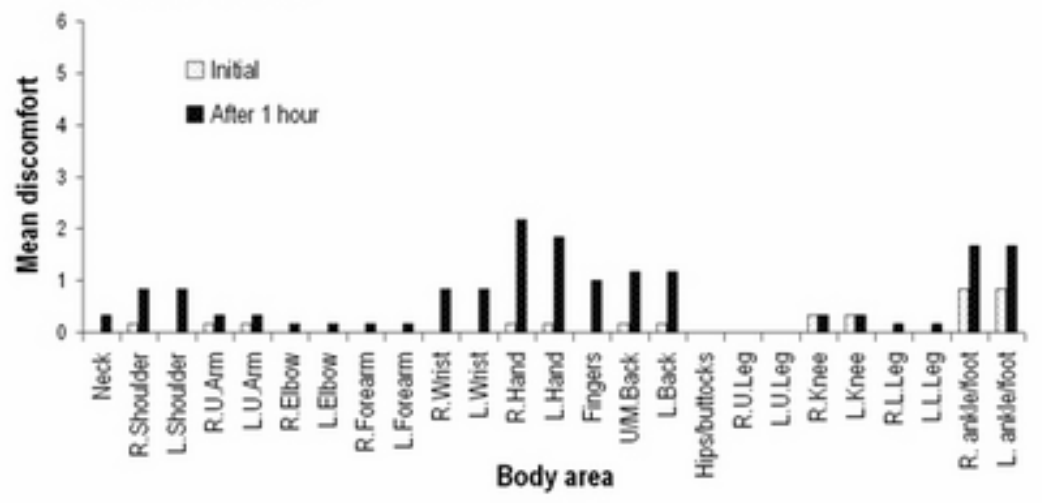

(b) Joiners ( $n=6)$

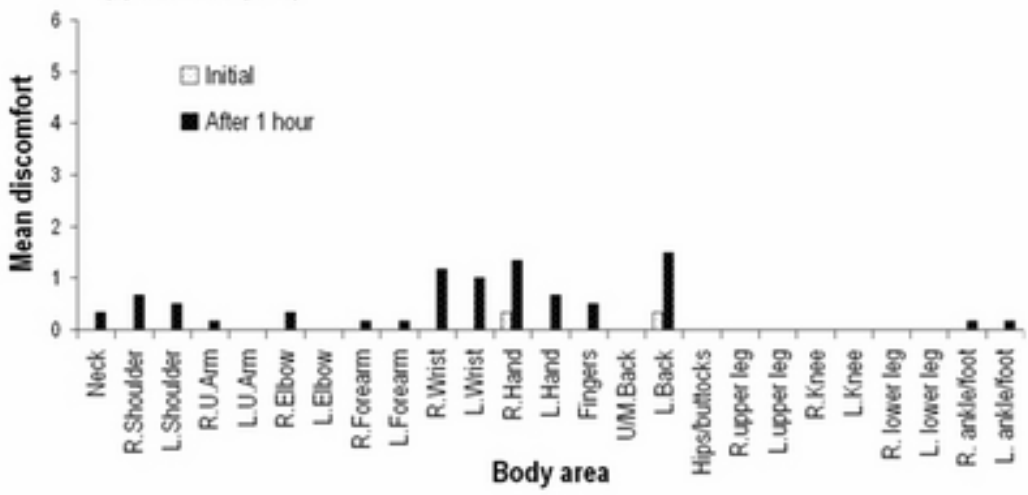

(c) Plumbers $(n=6)$

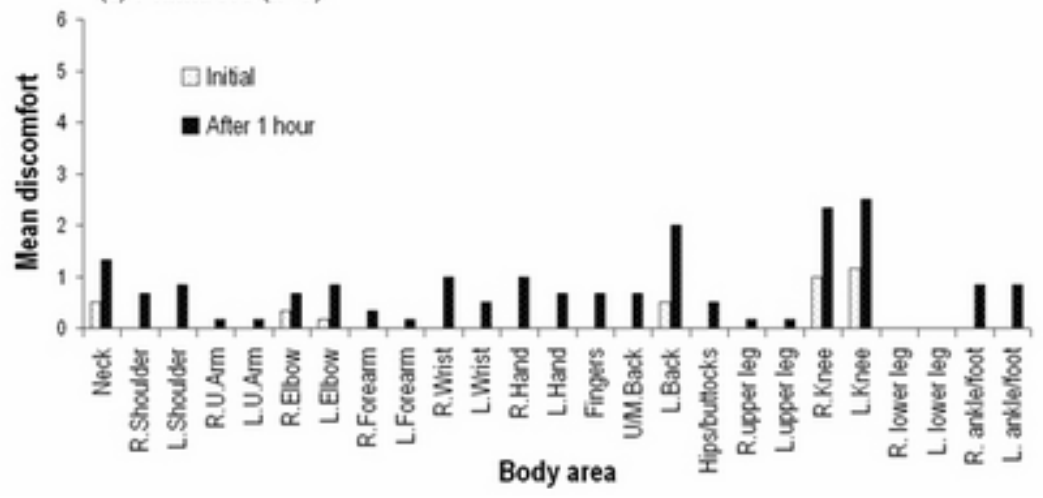

Figure 2: Mean Discomfort Ratings for (a) Cleaners, (b) Joiners and (c) Plumbers 
According to the stage of change questionnaire, the managers were in the maintenance stage indicating that they were working to consolidate changes made to behaviour. All six managers reported that they had taken steps (e.g. implementation of risk assessment and manual handling procedures, purchasing equipment to reduce risk of musculoskeletal problems) to reduce the risks to workers and had plans to introduce more efficient methods to reduce the burden on the workers.

Table 6: Characteristics of the Line Manager Participants $(n=6)$

\begin{tabular}{lcc}
\hline $\begin{array}{l}\text { Case } \\
\text { study area }\end{array}$ & $\begin{array}{c}\text { Participant } \\
\text { number }\end{array}$ & $\begin{array}{c}\text { Relevant work experience } \\
\text { (years): mean (SD) }\end{array}$ \\
\hline Cleaners' & 3 & $7.8(4.9)$ \\
Joiners' & 2 & $8.5(2.1)$ \\
Plumbers' & 1 & 33 \\
\hline \hline
\end{tabular}

The reported work experience of the line managers is shown in Table 6. Manager involvement in the task design decision were rated as high impact, with a mean rating of $8,8.5$ and 9 respectively with regard to the cleaners, joiners and plumbers. Managers also revealed that they were obtaining feedback from the workers on the equipment and processes, and were trying to reduce the effort required to carry out their job. These managers did not necessarily check whether the machines complied with the ergonomics guidelines, and relied on supplier information to obtain specifications and check for compliance by browsing technical specifications in the internet. All the managers had direct experience in the relevant work tasks and were using that experience in the decisions required for selection of equipment and processes.

\section{Discussion}

Prevalence data (Figure 1) shows that MSDs were reported among the workers in the case study areas. Previous research also shows MSDs in these workers (Ringen and Seegal, 1995; Kumar and Kumar, 2008). Further, differences in prevalence data among workers in the three case study areas could be observed (Figure 1). Cross-sectional studies by Ueno et al. (1999) and Holmstrom and Engholm (2003) with construction workers report a variation in MSD prevalence across different trades involved in the construction industry. They relate this variation to the difference in the level of physical exposure in different trades.

Cleaners reported musculoskeletal troubles in all body areas except the upper and lower legs, but they particularly reported shoulder (40\%), wrist (40\%) and low back (40\%) troubles in the last 12 months. Kumar and Kumar (2008) cite from the findings of several studies which reveals shoulder (63\%), wrist (46\%) and low back (36\%) prevalence in cleaners which are consistent with the current results. Similarly, Woods and Buckle (2005) also report that cleaning tasks affect the shoulders $(23 \%)$, hands $(22 \%)$, and low back $(43 \%)$. Joiners predominantly reported musculoskeletal troubles in the hands $(67 \%)$ and lower back $(50 \%)$. Although no literature was found specific to joinery, reports on studies of carpenters suggest 
MSD problems in the neck, shoulders and back (Albers et al., 1997). Prevalence data in plumbers was high for the neck (100\%), wrists (67\%), lower back (83\%) and knees $(83 \%)$. This is consistent with the findings of Rose (2007) where the research concludes that plumbers involved in pipe joining, experience musculoskeletal problems in the neck, wrists, low back and knees. Furthermore, this study emphasises problems in the shoulders and arms. Similar patterns of prevalence in construction workers in general (that include both joiners and plumbers) have also been identified where they report a high prevalence of shoulder, wrist, finger, low back and knee musculoskeletal troubles (Ringen and Seegal, 1995; Ueno et al., 1999; Holmstrom and Engholm, 2003).

However, it is difficult to directly associate prevalence data with musculoskeletal loading due to the work tasks studied because the workers engage in other tasks as well as the studied work tasks. For example, the cleaners that use the scrubbing machines also engaged in other cleaning tasks such as sweeping and mopping. According to Hildebrandt et al. (2001), in theory, an instrument used to identify risk groups with respect to musculoskeletal disorders, with the aim of taking effective preventive measures, should contain only items that show a prospective relation with musculoskeletal symptoms. Hence, it was important to evaluate the discomfort data in addition to the prevalence data.

Discomfort data collected at the beginning of the work task and after 1 hour of work (Figure 2) helped to identify mean discomfort as perceived by the workers specific to the studied work tasks. Cleaners showed a higher mean discomfort rating in the hands and ankles/feet. Joiners' WBD data showed a higher discomfort rating in the wrists, hands and in lower back. Plumbers showed a higher rating in the neck, lower back and knees. Although MSD prevalence and discomfort data show similar patterns, the small number of participants $(n=22)$ and the use of ordinal rating scales do not justify statistical verification of these effects (Gob et al., 2007).

The participants in the cleaners' study appeared to have less experience in the job than the participants in the joiners' and plumbers' studies. Unlike cleaners, joiners and plumbers require formal training and the jobs are considered as technical professions and as such, workers tend to remain in their particular field. Cleaning, whether using basic hand tools or using automated machines is a labour intensive and physically demanding job (Sogaard, et al., 1996; Woods and Buckle, 2005) and is mostly performed by people with a low social status and with a low level of education (Kumar and Kumar, 2008).

The stage of change questionnaire is used to categorise the process of change (Whysall et al., 2007). Five stages are identified: pre-contemplation (resistance to recognising or modifying problem behaviour); contemplation (recognising problems and thinking about changing, but are not ready to act); preparation (intending to change in the next 30 days and/or have made specific plans to do so); action (having made changes no more than 6 months ago); and maintenance (having made changes more than 6 months ago and working to consolidate gains made). According to this, all the workers in the three case study areas were in the contemplation stage. Interestingly in the current study, cleaners were also in the contemplation stage whereby they recognised the risks and were contemplating taking action despite their low level of experience and education as discussed in previous literature. Further detail regarding this is evident from the user-identified risks and requirements to reduce the risks as shown in Table 2, and cleaners' judgement of work-related factors for their musculoskeletal troubles. A comprehensive study by Woods and Buckle (2005) also indicates the ability of the cleaners to identify MSD risks. 
Although all of the workers were interviewed separately in this study, many identified similar risks and requirements. For example, all cleaners that were interviewed identified the 'need to lift and carry the dirty water tanks to empty' as a problem. Cleaners that reported low back troubles related it to bending and lifting. A high period prevalence of MSDs (Figure 1.a) and high mean discomfort (Figure 2.a) in the lower back for cleaners would appear to support this. The same task element (i.e. emptying containers) showed a high REBA risk level. Cleaners were able to identify risks and requirements for the task element with higher REBA risk, but they did not express concerns about task elements that showed low REBA risk levels (i.e. filling water was not identified as a problem by the cleaners). Similar associations between REBA risk levels and the user identified risks and requirements were observed in all case study areas: workers were in general able to identify work related-risks for the task elements that showed higher REBA risk levels.

The ratings regarding worker involvement in task design decisions for cleaners (mean= $2)$ were lower than that of joiners $($ mean $=4)$ and plumbers $($ mean $=5)$. This was a salient issue identified by Woods and Buckle (2005). High manager involvement in the task design decisions in cleaning may be due to the fact that the cleaners have low levels of experience and education as mentioned by Kumar and Kumar (2008). In addition, managers themselves were able to bring in their own experience of cleaning. In the case of joiners and plumbers, they have formal training and the experience to be involved more in such decisions.

All participants in all three case study areas identified risks and user requirements during the interviews suggesting the positive impact of participatory methods with users (workers). The favourable culture that participation brings into the work environments by giving responsibility to the workers has been discussed in research (Kuorinka and Patry, 1995; Kogi, 2006; Rivilis, et al., 2008). It will evoke a sense of ownership among the participants to the solutions that will be ultimately implemented and form a basis for lasting solutions and continuous improvement.

However, generalising the results of the current study to all work populations may not be possible due to the fact that the results are based on only twenty two participants and only three of the four categories of work environments and work tasks identified by Denis et al., (2008). Furthermore, there were only five female workers in the sample, although all workers that were involved in the studied work tasks participated in the study. Another limitation was that, according to the analysis of interview data, the workers found it difficult to separate risks from the design requirements needed to reduce work-related MSDs.

The QFD (Akao, 1990) based approach has been shown to have potential in obtaining and prioritising user requirements, solutions and other related information. Hence, the next phase of the research will involve further development of the QFD based participatory design approach and its evaluation. The design approach will have elements to help identify risks and user requirements to reduce work-related MSDs; prioritise them; identify design solutions using a TRIZ based approach; present the information using QFD matrices; check feasibility of solutions, and maintain a solution base. These elements will be evaluated using interviews and case studies. The proposed participatory design approach will help practitioners of health and safety, ergonomics, and design, to help provide design solutions for the work-related factors of MSDs thus ensuring worker health and well-being. 


\section{Conclusion}

Musculoskeletal troubles were present in all three case study areas (cleaners, joiners and plumbers). The majority (91\%) of the workers reported significant musculoskeletal troubles. All of the workers were able to identify risk factors in their job for work-related MSDs. Further, prioritised lists of user identified risks and requirements for the three case study areas were obtained from interview data.

\section{Acknowledgements}

The authors would like to thank the participating organisations and the participants for their invaluable support.

\section{References}

Akao, Y. 1990. Quality Function Deployment: Integrating customer requirements into product design. Productivity press, Cambridge, Massachusetts 02140, USA.

Albers, J.T., Li, Y., Lemasters, G., Sprague, S., Stinson, R. and Bhattacharya, A. 1997. An ergonomic education and evaluation program for apprentice carpenters. American Journal of Industrial Medicine. 32, 641-646.

Annett, J. 2005. Hierarchical task analysis. In: Stanton, N.A., Hedge, A, Brookhuis, K., Salas, E. and Hendrick, H. (eds.). Handbook of human factors and ergonomics methods. CRC press, Boca Ranton, FL, USA. 33-1.

Bao, S., Howard, N., Spielholz, P. and Silverstein, B. 2007. Two posture analysis approaches and their application in a modified Rapid Upper Limb Assessment evaluation. Ergonomics. 50, 21182136.

Broberg, O. 2007. The Workspace Design concept: A new framework of participatory ergonomics. In: Berlin, C. and Bligård, L.O. (Eds): Proceedings of the 39th Nordic Ergonomics Society Conference, Oct 1-3 2007, Lysekil, Sweden.

Buckle, P. 2005. Ergonomics and musculoskeletal disorders: Overview. Occupational Medicine. 55, 164-167.

Chan, L.K. and Wu. M.L. 2002. Quality function deployment: A literature review. European Journal of Operational Research. 143, 463-497.

Corlett E.N. 1990. The evaluation of industrial seating. In: Wilson J.R. and Corlett E.N. (eds.) Evaluation of human work: A practical ergonomics methodology. Taylor \& Francis, London. 500-515.

Denis, D., St-Vincent, M., Imbeau, D., Jette, C. and Nastasia, I. 2008. Intervention practices in musculoskeletal disorder prevention: A critical literature review. Applied Ergonomics. 39, 1-14.

Erlandson, D.A., Harris, E.L., Skipper, B.L. and Allen, S.D. 1993. Doing naturalistic Inquiry: A guide to methods. Sage publications, Inc. California, USA. 111-113.

Glaser, B.G. 1965. The constant comparative method of qualitative analysis. Social problems. 12, 436445.

Gob, R., McCollin, C. and Ramalhoto, M.F. 2007. Ordinal methodology in the analysis of Likert scales. Quality \& Quantity. 41, 601-626.

Goncalves-Coelho, A.M., Mourao, A.J.F. and Pereira, Z.L. 2005. Improving the use of QFD with axiomatic design. Concurrent Engineering: Research and Applications. 13, 233-239.

Hignett, S. and McAtamney, L. 2000. Technical note: Rapid Entire Body Assessment (REBA). Applied Ergonomics. 31, 201-205.

Hildebrandt, V.H., Bongers, P.M., van Dijk, F.J.H., Kemper, H.C.G. and Dul, J. 2001. Dutch musculoskeletal questionnaire: description and basic qualities. Ergonomics. 44, 1038-1055 
Holmstrom, E. and Engholm, G. 2003. Musculoskeletal disorders in relation to age and occupation in Swedish construction workers. American Journal of Industrial Medicine. 44, 377-384.

HSE. 2008. Self-reported work-related illness and workplace injuries in 2006/07: Results from the Labour Force Survey. National statistics, UK.

Iranmanesh, S.H., Thomson, V. and Salimi, M.H. 2005. Design parameter estimation using a modified QFD method to Improve customer perception. Concurrent Engineering: Research and Applications. 13, 57-67.

Kogi, K. 2006. Participatory methods effective for ergonomic workplace improvement. Applied Ergonomics. 37, 547-554.

Konz, S. 1990. Work design: Industrial ergonomics, Third Edition. Publishing horizons Inc. Scottsdale, Arizona. 45-47.

Kuijt-Evers, L.F.M., Morel, K.P.N., Eikelenberg, N.L.W. and Vink, P. 2009. Application of the QFD as a design approach to ensure comfort in using hand tools: Can the design team complete the House of Quality appropriately? Applied Ergonomics. 40, 519-526.

Kumar, R. and Kumar, S. 2008. Musculoskeletal risk factors in cleaning occupation: A literature review. International Journal of Industrial Ergonomics. 38, 158-170.

Kuorinka, I. and Patry, L. 1995. Participation as a means of promoting occupational health. International Journal of Industrial Ergonomics. 15, 365-370.

Kuorinka, I., Jonsson, B., Kilbom, A., Vinterberg, H., Biering-Sorensen, F., Andersson, G. and Jorgensen, K. 1987. Standard Nordic questionnaires for the analysis of musculoskeletal symptoms. Applied Ergonomics. 18, 233-237.

Marsot, J. 2005. QFD: a methodological tool for integration of ergonomics at the design stage. Applied Ergonomics. 36, 185-192.

Rantanen, K. and Domb, E. 2002. Simplified TRIZ: new problem-solving applications for engineers \& manufacturing professionals. CRC Press. Florida, USA.

Ringen, K. and Seegal, J. 1995. Safety and health in the construction industry. Annual Reviews of Public Health. 16, 165-188.

Rivilis, I., Cole, D.C., Frazer, M.B., Kerr, M.S., Wells, R.P. and Ibrahim, S. 2006. Evaluation of a participatory ergonomic intervention aimed at improving musculoskeletal health. American Journal of Industrial Medicine. 49, 801-810.

Rivilis, I., Van Eerd, D., Cullen, K., Cole, D.C., Irvin, E., Tyson, J. and Mahood, Q. 2008. Effectiveness of participatory ergonomic interventions on health outcomes: A systematic review. Applied Ergonomics. 39, 342-358.

Rose, L. 2007. Work with press jointing machines for pipe working: an ergonomic analysis. In Berlin, C. and Bligård, L-O. (Eds): Proceedings of the 39th Nordic Ergonomics Society Conference. Oct 1-3 2007, Lysekil, Sweden.

Ruotsalainen, J.H., Verbeek, J.H., Salmi, J.A., Jauhiainen, M., Laamanen, I., Pasternack, I. and Husman, K. 2006. Evidence on the effectiveness of occupational health interventions. American Journal of Industrial Medicine. 49, 865-872.

Sogaard, K., Fallentin, N. and Nielsen, J. 1996. Work load during floor cleaning. The effect of cleaning methods and work technique. European Journal of Applied Physiology. 73, 73-81.

Spielholz, P., Silverstein, B., Morgan, M., Checkoway, H. and Kaufman, J. 2001. Comparison of selfreport, video observation and direct measurement methods for upper extremity musculoskeletal disorder physical risk factors. Ergonomics. 44, 588-613.

Ueno, S., Hisanaga, N., Jonai, H., Shibata, E. and Kamijima, M. 1999. Association between musculoskeletal pain in Japanese construction workers and job, age, alcohol consumption and smoking. Industrial Health. 37, 449-456.

Vink, P., Imada, A.S. and Zink, K.J. 2008. Defining stakeholder involvement in participatory design processes. Applied Ergonomics. 39, 519-526. 
Whysall, Z.J., Haslam, C. and Haslam, R. 2007. Developing the stage of change approach for the reduction of work-related musculoskeletal disorders. Journal of Health Psychology. 12, 184197.

Woods, V. and Buckle, P. 2005. An investigation into the design and use of workplace cleaning equipment. International Journal of Industrial Ergonomics. 35, 247-266.

\section{About the Authors}

Himan Kanishka Gardiye Punchihewa

Himan graduated in year 2001 with upper second class honours in Mechanical Engineering from University of Moratuwa, the premier University in Sri Lanka for engineering education. He was then a Research Assistant in the Department of Mechanical Engineering on a Swedish International Development Cooperation Agency (SIDA) funded project on biomass energy. Himan was then awarded a scholarship to follow a Masters programme in Industrial Engineering and Engineering Management at the Hong Kong University of Science and Technology, Hong Kong in year 2002. Having completed his M.Sc., he went back to University of Moratuwa to take up a lecturer position in the Department of Mechanical Engineering in year 2004. He has involved in industry related and university based projects while teaching both undergraduate and postgraduate engineering students. After working in the department for three years, he was granted study leave and was awarded a scholarship to further his education in ergonomics at Loughborough University. His $\mathrm{PhD}$ is co-funded by Loughborough University and through a World Bank funded project to improve relevance and quality of undergraduate education (IRQUE) in Sri Lanka.

\section{Dr. Diane Elizabeth Gyi}

Diane is a Senior Lecturer on the Ergonomics programmes in the Department of Human Sciences at Loughborough University. She has significant experience of research in the area of health ergonomics (work related musculoskeletal problems e.g. driving, construction) and applying this to the design of products, services and systems. Recent and current projects include preventing and managing the risks of back pain in business drivers funded by the HSE/DoH (2000) and more recently by The Bupa Foundation (2007); developing ergonomics data, methods and tools for design teams (EPSRC 1999, 2004 and 2007); and improving the user experience of 'smart' home technology (the Dti, 2003). Previously, she has worked as an Occupational Therapist for 7 years which has given her insight into the damaging effects that poorly designed equipment and facilities can have on confidence, mobility and quality of life. Diane is currently a Scientific Editor for Applied Ergonomics, and a member of the Editorial Board for the International Journal of Industrial Ergonomics. She has also been a Member of several Networks e.g. the Steering Group of the EPSRC EQUAL Network (20012003) and the EPSRC Peer Review College (2003-2005). In addition, her research has been widely published in journals and conference proceedings. 



\section{DESIGN PRINCIPLES \& PRACTICES}

\section{EDITORS}

Bill Cope, University of Illinois, Urbana-Champaign, USA.

Mary Kalantzis, University of Illinois, Urbana-Champaign, USA

\section{EDITORIAL ADVISORY BOARD}

Genevieve Bell, Intel Corporation, Santa Clara, USA.

Michael Biggs, University of Hertfordshire, Hertfordshire, UK.

Thomas Binder, Royal Danish Academy of Fine Arts, Copenhagen, Denmark. Jeanette Blomberg, IBM Almaden Research Center, San Jose, USA.

Eva Brandt, Danmark Designskole, Copenhagen, Denmark.

Peter Burrows, RMIT University, Melbourne, Australia.

Monika Büscher, Lancaster University, Lancaster, UK.

Patrick Dillon, Exeter University, Exeter, UK.

Kees Dorst, TUe, The Netherlands; UTS, Australia.

Ken Friedman, Swinburne University of Technology, Melbourne, Australia;

Denmark's Design School, Copenhagen, Denmark.

Michael Gibson, University of North Texas, Denton, USA.

Judith Gregory, IIT Institute of Design, Chicago, USA; University of Oslo, Oslo, Norway.

Clive Holtham, City of London University, London, UK.

Hiroshi Ishii, MIT Media Lab, Cambridge, USA.

Gianni Jacucci, University of Trento, Trento, Italy.

Klaus Krippendorff, University of Pennsylvania, Philadelphia, USA.

Terence Love, Curtin University, Perth, Australia.

Bill Lucas, MAYA Fellow, MAYA Design, Inc., Pittsburgh, USA.

Ezio Manzini, Politecnico of Milano, Milan, Italy.

Julian Orr, Work Practice \& Technology Associates, Pescadero, USA.

Mahendra Patel, Leaf Design, Mumbai, India.

Toni Robertson, University of Technology Sydney, Sydney, Australia.

Terry Rosenberg, Goldsmiths, University of London, London, UK.

Keith Russell, University of Newcastle, Callaghan, Australia.

Liz Sanders, Make Tools, USA.

Maria Cecilia Loschiavo dos Santos, University of São Paulo, São Paulo, Brazil.

Lucy Suchman, Lancaster University, Lancaster, UK.

Ina Wagner, Technical University of Vienna, Vienna, Austria.

Please visit the Journal website at http://www.Design-Journal.com for further information about the Journal or to subscribe. 


\section{THE UNIVERSITY PRESS JOURNALS}

\section{The International
JOURNAL Of the ARTS IN SOCIETY}

Creates a space for dialogue on innovative theories and practices in the arts, and their inter-relationships with society.

ISSN: 1833-1866

http://www.Arts-Journal.com

\section{DESIGN PRINCIPLES \& PRACTICES}

Q:

Examines the meaning and purpose of 'design' while also speaking in grounded ways about the task of design and the use of designed artefacts and processes.

ISSN: 1833-1874

http://www.Design-Journal.com

\section{THE GLOBAL STUDIES JOURNAL}

Maps and interprets new trends and patterns in globalisation.

ISSN 1835-4432

http://www.GlobalStudiesJournal.com

\section{The Intermational OU LEARNING}

Sets out to foster inquiry, invite dialogue and build a body of knowledge on the nature and future of learning.

ISSN: $1447-9540$

http://www.Learning-Journal.com

\section{The Intemanaional ${ }_{\text {JUR }}$ INCLUSIVE MUSEUM}

Addresses the key question: How can the institution of the museum become more inclusive? ISSN 1835-2014

http://www.Museum-Journal.com

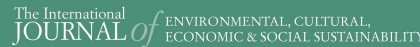

Draws from the various fields and perspectives through which we can address fundamental questions of sustainability.

ISSN: 1832-2077

http://www.Sustainability-Journal.com

\section{UBIQUITOUS LEARNING}

An International Journal

Investigates the affordances for learning in the digital media, in school and throughout everyday life.

ISSN 1835-2030

http://www.ULJournal.com

\section{Tho Intermanional $O f_{\text {ite }} \mathrm{BOOK}$}

Explores the past, present and future of books, publishing, libraries, information, literacy and learning in the information society. ISSN: 1447-9567

http://www.Book-Journal.com

\section{The International
JOURNAL Of DIVERSITY in ORGANISATIONS
COMMUNITIES \& NATIONS}

Provides a forum for discussion and builds a body of knowledge on the forms and dynamics of difference

and diversity.

ISSN: 1447-9583

http://www.Diversity-Journal.com

\section{The Inemational Of in HUMANITIES}

Discusses the role of the humanities in contemplating the future and the human, in an era otherwise dominated by scientific, technical and economic rationalisms.

ISSN: 1447-9559

http://www. Humanities-Journal.com

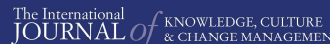

Creates a space for discussion of the nature and future of organisations, in all their forms and manifestations.

ISSN: 1447-9575

http://www.Management-Journal.com

\section{The International}

Discusses disciplinary and interdisciplinary approaches to knowledge creation within and across the various social sciences and between the social, natural and applied sciences. ISSN: 1833-1882

http://www.Socialsciences-Journal.com

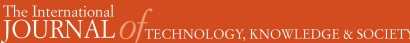

Focuses on a range of critically important themes in the various fields that address the complex and subtle relationships between technology, knowledge and society.

ISSN: 1832-3669

http://www.Technology-Journal.com

\section{JOURNAL of the World Universities Forum}

Explores the meaning and purpose of the academy in times of striking social transformation.

ISSN 1835-2030

http://www.Universities-Journal.com 